\title{
Not so Quiet on the New Zealand Front: All Quiet on the Western Front and New Zealand Memories of the Great War
}

\author{
STEVEN LOVERIDGE
}

\begin{abstract}
In 1929, ten years after the end of the First World War, many New Zealanders commented on how their memories and sense of the conflict sat with the representations emerging within contemporary popular literature. Much of this commentary cited Erich Maria Remarque's All Quiet on the Western Front which stood as the definitive example of a new more graphic and cynical presentation of the war emerging at the time.
\end{abstract}

Study of this commentary complicates some of the assertions of previous studies on the subject of New Zealand's memory and sense of the conflict. It suggests that, in 1929, New Zealander's held and advanced multifaceted, nuanced and, very significantly, noisy interpretations of the war. Evidently it was not so quiet on the New Zealand front.

Indicative, and typically taken as the definitive example, of increasingly graphic and cynical representations of the war emerging in the late 1920s, the arrival of Erich Maria Remarque's novel All Quiet on the Western Front on the New Zealand literary scene generated generous measures of commentary and controversy. In discussing Remarque's bleak vision, many New Zealanders cited their own memories and sense of the war. Their words give some insight into the state of New Zealand memory and memorialization of the conflict 10 years after its conclusion. This article considers the context of this episode, surveys the content of responses and considers some of the implications for our understanding of memory of the Great War.

\section{Context}

It is not an artificial categorisation of the historian to note that New Zealand society, circa 1929, was experiencing a shift in popular imaginings of the war. Indeed it was a development recognised at the time. As one commentator noted:

During the Great War, and shortly afterwards, we remember war books that were harmless and often humorous, as well as others that showed in a clear light the gallantry and patience of our troops... suddenly out of the open sky another very distinct type of books relating to the War appeared. It based its claim to notice on the ground of stark realism. ${ }^{1}$

Likewise, a 1930 British review of "war books" noted the recent appearance of a flood of war fiction of a type very different to what had come before. The defining characteristics of such works centred on a tendency towards more graphic depictions and a less ambiguous message of the horrors of war; "the writers have set themselves, not to strip war of its romance - for that was pretty well gone already - but to prove that the Great War was engineered by knaves or fools on both sides, that the men who died in it were driven like beasts to the slaughter, and died like beasts, without their deaths helping any cause or doing any good."2

It is tempting to read this shift against studies on war remembrance which note the potential for later commentary to diverge from initial representations. ${ }^{3}$ Jay Winter, for example, observes the tendency for cultural producers to "wear the mantle of consolation" in the aftermath of war, to reach for "tolerable or sanitized images of combat and violence." 4 Salient aspects of the trauma, hardship and challenges inflicted by the war included the deaths of some 18,000 New 
Zealanders and the adjustment of many to new statuses - widows, fatherless children, mourners, pensioners and invalids. ${ }^{5}$

These circumstances provide some context for the energy invested in efforts to heal, restore and repatriate. These efforts can be glimpsed in the endeavour to transition more than 80,000 soldiers back into the conventional masculine roles of productive wage-earners, dutiful citizens and, actual or potential, heads of families. ${ }^{6}$ Many appear to have welcomed these prospects and embraced the normal and familiar as a comforting relief. ${ }^{7}$ Assessing the re-entry of mid-late twentieth-century soldiers into civilian life, the psychologist S.J. Rachman observed that "the large majority coped extraordinary well" and some accounts hold this assessment as applying to veterans of 1914-1918 as well. ${ }^{8}$ Cultural responses to disruption and trauma can also be considered. Faced with disruptions, uncertainties and legions of mourners, it is unsurprising that commemoration and memorialization gravitated towards expressions of solace, reassurance and symbolic acts of putting the dead to rest. For many, such expressions also offered a way forward, providing a means to respond to painful memories, to come to terms and live with loss or trauma. ${ }^{9}$

However, the limits of positive renditions to sooth and comfort those unable to square their memories with such sentiments are also evident. "At times these positive narratives become intolerable to some of those who lived through these events." 10 Consequently, consolation commemoration can scatter the seeds for reactions and reinterpretations. Indeed, thousands of New Zealand men returned with ongoing health concerns, permanent disablements and instances of post-traumatic stress. ${ }^{11}$ These circumstances played out in contrast to wartime rhetoric of a better post-war order and against the idealised conceptions of home that soldiers on duty tend to develop. ${ }^{12}$

Awareness of such circumstances assists us in mapping some prominent features of the emotional landscape and the context of popular post-war representations of the war. It is, for example, unsurprising that much early literary production - novels, histories, memoirs - trod carefully in approaching memory of 1914-1918. This, it should be noted, did not necessarily mean the avoidance of gruesome details. Many productions drew upon first-hand military experience and did not shy away from addressing "mud, blood and horror." On the international scene, Peter Jackson, Cigar Merchant, written by the veteran Gilbert Frankau and published in 1920, became the first post-war novel to sell more than a 100,000 copies and the title reached New Zealand readers. ${ }^{13}$ The book's presentation of the front is hardly saccharin in content or tone:

Suddenly Peter grew aware of noise. A noise inhuman. The whimper of damned souls. A wail as of enormous wet fingers on an enormous glass: a wail that rose and fell, interminable, unbearable. Suddenly he was aware whence that wail came. All along the muddy roadway they lay - the wounded: hundreds of them: thousands: brown blanket shapes: some muttering: some moaning: some singing in delirium: some quite still. The agony of it gripped Peter by the stomach. Vomit rushed to his throat; was choked down again. ${ }^{14}$

What does distinguish this material from later works is the sense woven around the darker aspects of the war experience. Despite Paul Fussell's influential and controversial claims that the war discredited traditional expressions, conventions and rhetoric, revealing them as irreconcilable with the war experience, these productions continued to speak a language of heroism, bravery, duty, sacrifice and purpose in making sense of the horrors of war. ${ }^{15}$ Describing the graphic descriptions within Peter Jackson, Cigar Merchant, Dan Todman notes "The meanings that were derived from these experiences were more positive than we might expect. It was possible to make sense of the war by emphasising participants' willingness to undergo such horrors in defence of the nation." "Such approaches are also prevalent within the first generation 
of New Zealand's written remembrance which includes official histories, unit histories and popular histories. Within these works great losses of life and traumatic aspects of the war experience are typically referred to in a context of military purposes or with reference to higher ideals. ${ }^{17}$

The earlier works also featured a relative ambiguity in their moral judgement of the war meaning that "it was the reader or playgoer who decided whether or not a work was "antiwar". 18 At times assessments appear to hinge almost entirely upon the reader/viewer. For example, New Zealander's both celebrated and condemned Robert Sherriff's Journey's End (1928) - probably the most popular dramatic representation of the war during the 1920s/30s - and Robert Graves' memoir Goodbye to All That (1929) for their "anti-war" messages. ${ }^{19}$ These assessments would have surprised the authors; Graves observed that he had rather enjoyed parts of his military service, whilst Sherriff noted that, while he had found the war hard to endure, he wrote Journey's End in part to celebrate the public school ethos he felt had underwritten Britain's struggle. ${ }^{20}$

All Quiet on the Western Front secured its place as the gem of the cynical and directly anti-war approach, the title itself becoming a proverbial reference for the novel's presentation of the frontline experience as a profoundly dehumanising one. The novel focuses on the experiences of Paul Bäumer, a young German soldier stationed on the Western Front. In outlining the conditions Paul and his comrades endure, the precise details of the war - its battles, origin and purpose - are left vague and essentially meaningless to the men in the trenches; one soldier's question of "what exactly is the war for?" brings forth various disillusioned responses and the resolution that "the best thing is not to talk about the rotten business." ${ }^{21}$ Instead Paul comprehends the war as an inescapable presence - images of disease, whirlpools and cages are used - which brutalises the men; "it has transformed us into unthinking animals in order to give us the weapon of instinct... it has lent us the indifference of wild creatures". ${ }^{22}$

This loss of self is most apparent when Paul returns home on leave and, whilst recognising the town as unchanged, notes "I do not belong here anymore, it is a foreign world." 23 His estrangement extends to those unable to relate to his experiences and Paul displays frustration towards those whose attitudes and sentiments he finds uncomprehending and trite. Such alienation is held to extend beyond Paul's story and Remarque's preface claims the book is about "a generation of men who, even though they may have escaped its shells, were destroyed by the war." 24 The novel concludes with Paul's ironically charged death in the last days of a war that has become a lost cause. An army report, consisting of a single sentence, confirms his death as without impact, simply noting "All quiet on the Western Front." 25

Cultural and commercial links connected New Zealand's literary world with this flood of war books. One account observes the early thirties as the period when "shops and libraries were full of books, fictional or otherwise, whose moral was the horror and futility of war"; a smattering of local examples, appearing in the mid/late 1930s, might also be identified as being influenced by this style and trend. ${ }^{26}$ All Quiet on the Western Front was amongst those stocked and copies of the book reached New Zealand in May 1929, pre-empted by an innovative advertising campaign, words of praise that it represented the long-awaited great novel of the war and controversy around the book's content and handling of its subject. ${ }^{27}$ Many libraries elected not to purchase the book, sometimes without comment, sometimes noting some variation on the idea that the book's crudity meant it was not suitable for public consumption. ${ }^{28}$ Despite restrictions, book and readers found one another. A New Zealand Observer cartoon in July quipped at how controversy and restrictions had served to spur curiosity and interest (fig.1). In the central image a librarian obstructs a personified copy of the text from entering the library stating "you're unfit for our company. Go to the public they'll rush you." Indeed private booksellers reported a brisk demand for the title with shipments selling out in days and with hundreds booking copies. ${ }^{29}$ Additionally, some libraries bucked the trend. By the end of June 
1929 the Dunedin Athenaeum possessed two copies and was ordering another six to meet demand. ${ }^{30}$ Canterbury Public Library elected to issue the book upon application while the Te Kuiti Library Committee and the Waihi Library Committee decided to distribute the title to adults only. ${ }^{31}$

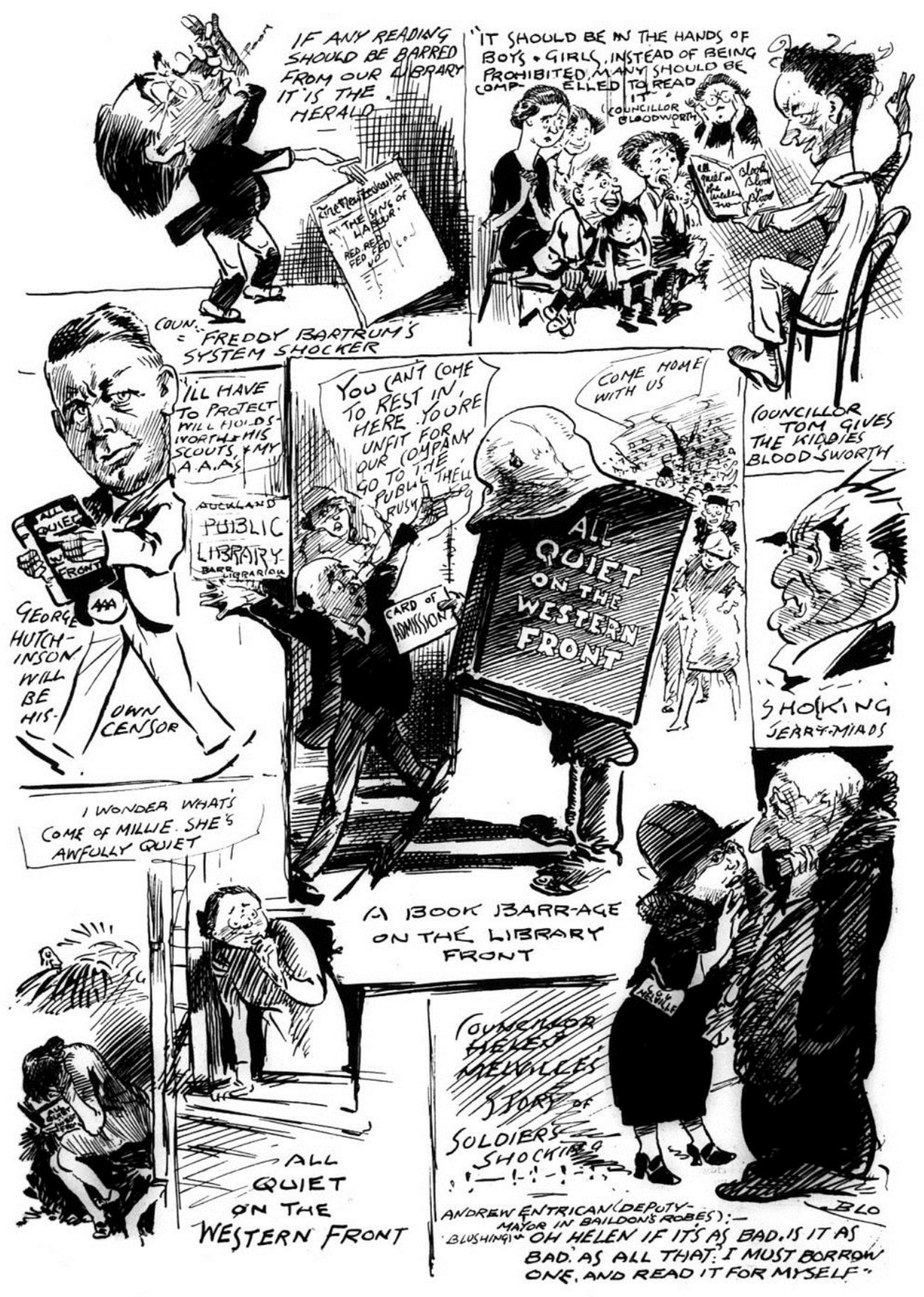

BARRED AND BANNED: ALL IS NOT QUIET ON THE TOWN HALL FRONT WHEN THE CITY FATHERS-AND

Figure 1 New Zealand Observer, 19 July 1929, 17. 
Anecdotes also hint at the prominence the book gained in the reading landscape with one reader claiming $\mathrm{s}$ /he had read the text five times and was "mediating a sixth perusal." ${ }^{32}$ In the literary section of one newspaper the editor confessed that he was "frequently guilty" of indulging in a game of spying on what female tram passengers read and trying to match the book with the personality of the reader:

I generally turn away in disappointment, for what do I see? Again and again some love-sick novel is in her hands. The style of relaxation that should be insufferable after our teens... And I have been rewarded - rewarded with shock that has taken me from the depths of gloom to a state of intense amusement ... She was a lady not young, not old, but with a slight severity of expression which might have meant a rigid adherence to the conventions. She read as if entranced. And I suppose the last thing I expected to see when I peeped was All Quiet on the Western Front. Mentally I approved her moral courage. Bans or no bans, she would read it, and in a tram car, too. Why look for solitary corners, as many less courageous might? ${ }^{33}$

Indeed awareness of the book, or at least the title, grew to a sufficient extent to make "All Quiet" a common cliché and a shorthand reference for the book's style and themes. ${ }^{34}$ Consider University Colleges' 1930 production of a comic farce entitled "All Quiet on the Waterfront" - "Doubtless it will be subject to some rude Remarques" added one wag. ${ }^{35}$

\section{Reactions}

It was within this context that the text's popularity/notoriety spurred reminisces upon the war. Commentary appeared alongside the book's arrival and proved a recurring topic within newspaper literary corners and letters to the editor. Renewed debate over the book's contents and merits flared with the release of a sequel, The Road Back, in 1931 and when the cinematic adaptation was temporarily banned in July 1930; this ban was later reversed (in August) and the film was released with cuts made to objectionable content around language, sex and drunkenness. $^{36}$

Alongside external events, ongoing debate was prompted by how, in contrast to later decades, public sense of the Great War in 1929 had not hardened around comprehensions of a war defined by futile suffering. Assertions sparked agreements and support or rebuttals and counterpoints, sometimes bringing stark tensions over how representations of the war complemented or clashed with personal sense/memories of the war. Indeed, despite the prominent tendency of commentators to pepper their points with unanimous claims - i.e. "all would agree that ..." or "no one would dispute ..." - one of the foremost characteristics of commentary is the differences over what the war had meant and how it should be represented. Many responses also reveal nuanced positions with multiple lines of argument and multifaceted views touching on a variety of issues. Thus the cause of the war, whether the war had been badly managed, the conduct of troops, the character of the enemy and the lessons of the war often formed distinct subjects within overall assessments. Perspectives on these points were often characterised by ambiguities and, intricate differences of opinion. A commentator might acknowledge self-inflicted wounds and firing squads but defend the officers and the necessity of the war. Another might deem the war's outbreak as indicative of human folly but note that men truly had embodied heroic ideals and formed an egalitarian brotherhood.

This subjectivity extended to readings of the text itself. The reviewer "Cyrano" deemed All Quiet on the Western Front a downbeat read, a "story of utter disillusionment ... the war is a hideous task, in which men fight men, live in filth, eat like animals." 37 Another reader appeared to find inspiration in the text and noted "... after reading it, one realises the divine message that is in this book ... that message is love of peace, and a greater understanding and tolerance for each other; in short the meaning of the word brotherhood." ${ }^{38}$ Even in 1930, with 
All Quiet on the Western Front becoming enthroned as the gem of the anti-war canon, subjective reactions are evident. This is neatly illustrated in a letter one man wrote to the censor regarding the banning of the cinematic adaptation of All Quiet on the Western Front. Noting that as an 18 year old that he had volunteered and been rejected for service, he protested the censorship of the film. This was not because he approved of representations of the war that emphasised the bleak realities of the front and the futility of the war but because he took the opportunity to see "every war picture that has come here" and because he felt that society, and particularly the young generation, should "know all about the momentous history that was made in their day. It helps us to understand history and gives us a wonderful insight into what was done for us, should we build up patriotism, loyalty to King, Empire and Country, good citizenship etc. etc." 39

However, surveillance of public reactions to All Quiet on the Western Front indicates that discussion often revolved around various contemporary concerns. Three major issues can be identified as sitting at the nexus of discussions over 1929-1930. Namely:

(1) Did the text's "realism" represent a more truthful representation?

(2) Did the war degenerate soldiers?

(3) What moral lesson(s) should be connected to memory of the war?

The answers offered to these questions raised issues around what soldiers had experienced at the front, how those experiences should be considered and, in turn, how posterity should remember the war.

\section{(1) Did the text's 'realism' represent a more accurate representation?}

A rather elementary aspect of the debate, but one on which other premises rested, was whether the new approach to literary depictions of the war conveyed a more accurate account of soldiers' experiences. The Evening Post's review of All Quiet on the Western Front simply noted "It sometimes is revolting and coarse, its simplicity carrying the stamp of truth in every line." ${ }^{40}$ This sense of truthfulness was not inevitably cited as a line of support. Indeed a Wellington librarian supporting Auckland Library's decision not to stock the book argued from such a premise. "It is not a book that should be circulated freely to the public. Of that there is not the slightest doubt.... The language in the book is coarse and lurid, just as used by soldiers, as those who served know. I think we have a duty to the public." 41 In response to such attitudes, the hardly cage rattling Auckland Star penned a few verses ridiculing the attitude that the "dreadful truths" about the war should not be revealed:

Dear brethren, don't you really think

That this essay in printers ink

Is rather strong for folk like us?

There may be naughty words, you know,

Among the dreadful truths - and so

Dismiss it with a hearty cuss.

The book may do for wicked folks, Scots, Irish, English, Slovaks Croats. Germans and French and Esquimaux.

But why should evil enter here.

Where all is sinless, lovely, fair?

Shall we have truth? Good gracious, no! ${ }^{42}$ 
Indeed the sense of vulgar authenticity won the book supporters. R.M. Thomson, offered a praising review of the book, noting "let us honour the man, Remarque, who has the courage to show war's true hideous and atrocious brutality... no one knows the ghastly, insane, senseless, utterly useless brutality of war more than I do." 43 Some went further and argued that not confronting unpleasant aspects of the war cheapened remembrance. "Soldiers Daughter" for instance noted:

It makes me angry to think that some people condemn this book. They think it is too nauseating and coarse for them to sit and read it in their comfortable armchairs at home, when our men - our brothers, fathers, and sweethearts had actually to endure all those horrors, and tragedies. After all their suffering surely it is good enough for us to read about and I recommend every woman to let her son and brother read it, and so get it out of his head that war is a great adventure. ${ }^{44}$

For some readers this notion of All Quiet on the Western Front as offering a glimpse of the unsanitised, unglamourised truth of the frontline experience made reading it a solemn and intimate experience. "Constant Reader" noted this was a book "to be read in silence and alone and as the pages are turned there will grow upon the reader a sense of shamed responsibility that the horrifying thing set down should actually have occurred ... The descriptions in all their bestiality and indecency bear the stamp of absolute truth." 45 One wonders how common the image of a reader sobbing into the text, as depicted in the lower left corner of fig.1, was.

It was inevitable that some of the tens of thousands of New Zealanders who had served during the war would wade into the debate - many elected to sign their letters with their wartime serial numbers. Many agreed that the work was a fair depiction. "12/4163" acknowledged that "No doubt the book is stark, grim and coarse, but so is war. Too long has there been a conspiracy of silence on these matters, and it is right and proper that those men who were too young or too old or too important to go to the war should know what the real thing is." 46 Other assessments were more qualified. Rev. Ronald S. Watson noted that "On the basis of eighteen months' experience with the troops in France I have no hesitation in saying that the picture presented is substantially a true one for either side of the fighting line." ${ }^{47}$ Another writer, " $1 / 435$," noted "leaving out the objectionable material referring to the morality or should I say the immorality of men, the book is, I think, most descriptive and a true picture." 48

However, the sense of such literature as offering a more truthful representation of the soldiers' war was also extensively questioned, critiqued and rejected. "Sapper" responded to the aforementioned claim that soldiers' regularly used "coarse and lurid language" with "I do not suggest that the soldier never went beyond the word 'bother,' but his language and behaviour were certainly no more coarse and lurid than that of any other gathering of men in the absence of womenfolk."49 Likewise, "Infantry Company Commander" protested what he claimed was a "sordid misrepresentation of the facts," noting that "It is utterly wrong that the sacrifices of those who suffered and fell, and those who served and returned, should be exploited in this manner." 50 W. Perry added similar sentiments:

I venture to say that the majority of ex-servicemen who have read it [All Quiet on the Western Front] are thoroughly "fed up" and astounded at the wonderful reception that has been accorded Remarque's book. I have discussed the book with at least fifty ex-servicemen of all ranks. Two, an officer and a private, approve the book; the remainder unanimously condemn it. And they condemn it for two reasons: first because of its indefensible coarsenesses, and secondly because of the author's indulgence in grossly exaggerated generalities... If the author of this very coarse book and his comrades were true types of the German army (which I am loath to believe) then thank God our army was not like theirs. ${ }^{51}$ 
A common claim raised by commentators rebutting Remarque's representation was that the work misleadingly gravitated to extremes and presented them as typical. For example, Colonel Powles noted:

The man who wrote All Quiet on the Western Front is a man who, if he was in Wellington, and saw a drunkard would follow him home and note everything he did; he would follow a Chinaman down his alley; he would go to Porirua and inspect the inmates of the asylum; he would inspect all that was retched and sordid about the city, and then he would write a book about Wellington. He only saw one side of it and it was not the best. ${ }^{52}$

"2/99" concurred with the more succinct rendition that "All Quiet on the Western Front is a disgusting book, and is as representative of the war as a whole as the sewers under Wellington are of the city." ${ }^{, 53}$ Other veterans invoking this argument cited specific elements they felt were misrepresented. "AIF," for example, juxtaposed popular representations against his own memories:

My own experience does not embrace one instance of a soldier drinking himself constantly and consistently into a state of "Dutch courage" ... I know no instance of a man preferring suicide to the continued fighting ... The vast majority of the men were decent likeable human beings, and very far removed from the morbid, fainthearted creatures some would like to present as normal products of war ... Far from being the common order of the day, self-inflicted wounds and firing squads were an infinitesimal decimal of 1 per cent of the total men involved. ${ }^{54}$

"N.Z.E.F." wrote in agreement that "... the neurotic types were in a very definite minority." 55 F. Robertson also concurred "As a member of the N.Z.E.F. throughout the war, I feel impelled to say that it was not my misfortune ever to encounter any one [sic] near an approximation of the types portrayed by the company commander and all except one of his officers." 56

\section{(2) Did the war degenerate soldiers?}

Obviously discussions over how realistic All Quiet on the Western Front was went beyond an abstract debate on historical accuracy. As some of the above commentary suggests the fundamental contrast between All Quiet on the Western Front's central theme of the destruction of innocence and idealism and cultural conceptions of the soldier as embodying heroism and duty often came to the fore.

Pre-1914, soldiering had often been presented as possessing an ennobling quality. The New Zealand Herald's 1909 assertion that compulsory military training would work to make young men physically, mentally and civically fit by promoting "a soldierly walk and the physical development of the chest muscles" instilling "a hatred of slouching gait and slouching thoughts, of shirking work and evading responsibilities, of habits which demoralise and enfeeble" is a fairly typical rendition of this philosophy. ${ }^{57}$ Such conceptions of military service had been enlisted during the war and visions of clean-limbed, virtuous soldiers embodying ideals of patriotism, duty, righteous resolve and, increasingly, sacrifice had formed a prominent piece of cultural capital. $^{58}$

Years of industrial warfare on the scale of the First World War would challenge some of the more melodramatic imaginings around soldiering. Various studies have highlighted aspects of New Zealand soldiers' experiences - notably drinking habits, high VD rates and instances of violent disorder - at odds with romantically heroic visions. ${ }^{59}$ Within New Zealand, war weariness, the sight of returned wounded, letters from the front touching on frontline conditions that pierced the censor net (some of which were published in major newspapers) and years of casualty lists likewise contested ideas of heroic glamour. ${ }^{60}$ However, neither front saw 
a total abandonment of all understandings of heroism or idealism in the face of fire. ${ }^{61}$ Indeed, as will be seen, it was precisely because aspects of the war were unpleasant, demanding and horrific that some argued that conventional sentiments around duty and heroism were fitting and proper means to comprehend it by.

The sense that soldiers had confronted the trials of the war in an admirable fashion was starkly inverted within the new wave of war books where war is portrayed as a degenerating affair. As Mr A.B Charters put it "They [the new breed of war books] show not so much the black part of the war, but the blackness of the character of the soldiers. They make out that war brings out everything that is bad in man."62 John A. Lee's 1937 novel Civilian into Soldier offers an illustration of this deterioration of civilised behaviour and a sense of the radical re-valuing worked by the logic of war. In one scene from the novel New Zealand soldiers scavenge homes for fuel, sacrificing the physical and cultural heritage of an older, more decent, age for base needs:

First then, the furniture. A chair would feed the flames, a table would follow. An axe would tear polished mahogany off a grand piano... Thus it was that ceilings, beams, whole houses, humble deal tables, and aristocratic grand pianos, beds that had weathered the love and birth of centuries, were fed to the flames ... all yielded for a moments warmth ... property had lost its sanctity but not its power as a fuel. ${ }^{63}$

This aspect of All Quiet on the Western Front raised interest and various reactions. The veteran Pat Hanna reported that since the book had hit the shelves he had been much asked "Did the war debase men as much as there described?" He offered his position that "every Digger would say 'yes certainly." 64 Some commentators offered qualified critiques. "Cyrano" noted "It is easy to see why the book has had such a vogue ... It appeals to the spirit of revolt against war ... It is not the whole truth about war, for war, despite its cruelty and foulness and lunacy, has its ideals." 65 One veteran, F. Robertson, noted "what a ghastly crime against humanity the war was, but with all the degradation inseparable from it, men did not sink to the level some morbid minds would have us believe." 66 Some social voices made still more strident denouncements. For example, the Catholic magazine The Month published a condemnation of that "distinct type of war book" - though largely referencing Remarque - which focused on sordid behaviour:

We deny their "realism." These nauseous publications would proclaim to the world that the men who fought our battles, and suffered and died, were brutes and beasts, and their morals where on par with pigs. These are the very heroes to whom we have erected monuments in every city and town and village in our land. ${ }^{67}$

Others noted their approval and sense that presentations of the war as an unambiguously degenerating experience would aid public comprehension. "R.S." claimed that Remarque had "ruthlessly exposed" the realities of the front and that "those to whom All Quiet on the Western Front will administer the most violent 'shocks' are the people who up to now have hugged the delusion that even in the poison gas clouds of war there is a silver lining of romance." 68 Some veterans similarly argued that the book offered a cathartic means to impress a sense of their experiences. Bertram Potts wrote positively of works detailing the horrors of war, noting that All Quiet on the Western Front:

tears away the glamour and gives our children - and particularly the women folk an idea of what war means. To see and hear a man die an agonising death on the battlefield, cursing his fate, quickly disillusions the mind about "dulce et decorum est pro patria mori." 69

Likewise "Aprez la Gruerre Fini" (after the war finish) argued that:

... we who suffered for those weary long years of legalised murder should assist, to the very limit of our abilities, any attempt to show our people at home, the mothers 
especially, that the most degrading thing one can imagine is war. Let us show the world of people who did not go to the last war just exactly what we soldiers went through. ${ }^{70}$

R.M. Thomson "Ex-Main Body, N.Z.E.F." added that "no language in the wide world, however 'gross' it may be, can ever exaggerate its [wars] effects upon the finest qualities of the human soul, which it corrodes and destroys like vitriol." 71 In a later letter he added:

In fact, modernised warfare is not a time for normal minds at all. It is a time in which men return to their jungle, ancestry. They are abnormal, and everything connected with war becomes gross and pathological. This is the lesson for people ... who still seem to be living in a realm of war-time glamour and, romanticism ... The beastliness of war is not "insulting our soldiers" at all. It only illustrates how we were all victimised by its madness. ${ }^{72}$

Others rebutted this sense of the soldier as a victim. J.W. Thompson "(11/2244)," writing in response to Thomson, argued that "at least 90 per cent" of New Zealand troops with combat experience "had very little time or inclination to go in for any sort of beastliness."73 Some went further and asserted that the war had indeed had an ennobling effect, spurring men to heroism and self-sacrifice or instilling them with a sense of participating in something greater than themselves. W.M claimed that "many have returned from the war strengthened in character with a higher sense of duty, comradeship and sacrifice... If we could carry into our civilian life the same spirit of duty, sacrifice and comradeship we should be far on the road to the building of the ideal republic." 74 Another veteran added that "In place of a horrible deterioration in men, there was a broadening of their outlook on life, a deepening of their understanding, and the kindling of that gentle warmth of good comradeship." 75

\section{(3) What moral lesson(s) should be connected to memory of the war?}

Arguments over the nature of frontline experience were often linked to larger judgements of the war itself. Indeed many commentators displayed awareness that the present was setting precedents and weighed in on how the war should be remembered and what lessons should be imparted to posterity. Throughout 1914-1918, the sense that New Zealand's war effort was a necessary and righteous cause waged to prevent a German conquest of Europe had formed a dominant public message and many wartime participants would continue to assert this sense of the war for the remainder of their lives; five decades after the Gallipoli campaign Cecil Malthus argued that the instinct to oppose German domination in Europe was "profoundly right"; elsewhere he remarked that Remarque's book, while "often terrible and impressive," had "invent[ed] grotesque absurdities."

However by 1929 the interpretation of the war as representing a necessary and/or noble sacrifice had come into some dispute. New support for pacifism, disarmament and international co-operation grew in the interwar years and voiced some of the most direct and passionate commentary on the subject. ${ }^{77}$ In 1930 a conservative government ended compulsory military training on grounds of economy but also noted that "we cannot ignore the strong feeling in favour of world peace and the opposition to militarism ... which has grown up, not only in New Zealand, but in most other civilised countries." 78

Discussion around All Quiet on the Western Front also reflected this contemporary interest. Many proclaimed that the war's ultimate lesson was that it had been a mistake which must never be repeated and identified the new wave of war books as aligned with their cause. Correspondents of this outlook argued that, in order to instil a rejection of war, those who had not directly experienced the war's horrors - women and the young are often specifically mentioned - should be exposed to literature which would evocatively impress it upon them. 
Listing various titles, "No More War" proclaimed "let every thinking person read these moving words and we are surely one step nearer the great world-wide aim - peace."79 "PAX" agreed, asking:

is it not better to paint war in such a way that our children will not make the same mistake that their fathers did? War is not a noble thing, and let us strip it of all its glamour and show it to our youth in its horrible reality so that they will come to regard it as something to be prevented at any cost. ${ }^{80}$

Again, All Quiet on the Western Front enjoyed a central part in the deliberations. Reviewers like "Literatus" argued that it exposed "in trenchant terms" "the sheer folly of war as a means of settling disputes." 81 "F.H.H." agreed: "All Quiet on the Western Front is a work which, if unbanned throughout the country, will be bound to work for the ultimate good of the people, for the simple reason that always will it keep the people alive to the horrors of war and prevent them from taking rash steps that might involve us in another struggle." 82 Some veterans concurred. "Returned Sister" wrote "In my opinion, books like All Quiet on the Western Front have come at a most opportune time ... Let all men who haven't been, also mothers and wives, read these books so that they might realise in some small degree the waste, the horror, and the utter uselessness of war." 83

However, other commentators rejected the idea that the lesson of 1914-1918 was that people, and particularly future generations, should unconditionally renounce war. Arguments in this vein maintained the wartime conviction that New Zealand's/Britain's war had been one of necessary self-defence and principle. According to "Citizen":

In 1914 that was the only alternative and as men were men then, the flower of the Empire went bravely and willingly to force Germany back... Peace with honour should be everyone's desire, but not peace the only thing that matters... Thank God for the men who fought. May England find men and women who if necessary will fight again. ${ }^{84}$

Similarly "2/99" claimed the idea of "peace at any cost" neglected acknowledging of the costs of capitulating to aggressors:

When the war broke out on the Continent we had to decide whether to fight or not, and took the only course consistent with honour and self-preservation ... And if those who follow us into the still greater future of our race have again to make the fateful decision to fight or perish, what will their answer be ${ }^{85}$

If such commentators rejected pacifist notions that there was nothing worse than war, it is curious to note the range of sentiments they countered with. Some went further than arguing on strict terms of grim but necessary sacrifice. One commentator rejected moral equivalence between belligerents and asserted the necessity of going to war - "Let us remember that in 1914 a group of Powers wished for world domination" - but ran this premise alongside a sense that the war was a victory won by "undoubtedly some of the most glorious deeds in the annuals of British history." "Vincat Amor Patriae" (Love of Country Conquers), for example, claimed that "Most of us who had the privilege of fighting for our country in the Great War frequently have another question asked. 'If another war broke out would you go to it?' I believe the majority answer, 'Yes."' [sic] ${ }^{87}$ Perhaps the most striking perspectives are from those veterans who acknowledged the cost of war and the value of peace, yet strongly asserted their sense that the war should not be regarded as meaningless or futile:

All of us are agreed that the war was a tragedy and none of us would deny its horrors ... none of us want to go through it again. Few of us wanted to go through it the 
first time... Most of us went through the war, not through a liking for such pursuits, but because we deemed it necessary. The critics of our actions and ideals infer that we should have refused to fight and that the enemy was imaginary. Personally, I think that such teaching tends to undermine our character individually and as a nation. It tends to dull our perception, and asks us to bow to the whip of the masterbully. ${ }^{88}$

Commentary on the war's necessity often ran alongside the sense that the war was a lesson of the costs of preserving national freedoms, interests and values. Remembrance of the war, it was argued, should honour those who had fought as making a worthwhile sacrifice (for the survival of the nation/empire and an honourable peace) which future generations were entrusted to respect and uphold. Turning to posterity, one commentator asked "We did our best in the last war, and the next that comes along is going to be your job. What are we going to do?" 89 In retrospect, this, of course, was not a rhetorical issue; a ten year old flicking through this commentary on their way to the children's section would be of working/military age in ten years time when the country was again at war.

\section{Conclusion}

The reception of All Quiet on the Western Front offers a small reflection of New Zealanders' sense of the First World War at the end of the 1920s. Dissecting the commentary's anatomy reveals the tensions around personal memories of the war and this has several implications for our understanding of New Zealander's memorization of the conflict.

Perhaps the foremost implication is how these tensions illustrate remembering as "an active process of seeking to make sense of the past." ${ }^{90}$ New Zealander's experienced 1914-1918 from a variety of vantage points with even common experiences being processed and valued differently. Consequently, there never was a universal conception of the war experience and this subjectivity marks one origin point for conflicting claims of what "everyone who was there would agree" on. Post-war efforts to represent the war continued this process of assessing personal memories and making sense of the conflict. Consequently, what memories of 1914-1918 were recalled circa 1929, and what sense was made of such recollections could also reflect post-war contexts and reflections; indeed some have claimed that Remarque's work was more reflective of the setbacks of his post-war career than his wartime experiences. ${ }^{91}$

Examples of memories being rehearsed to reflect the way the war was being talked about are available in Alister Thomson's documentation of instances where Australian veterans' memories became composed around Anzac mythology. ${ }^{92}$ However, we can also see instances of memory being interpreted with reference to the new representations of the war like All Quiet on the Western Front. The ongoing process whereby memories were assessed within or against various representations of the war should be borne in mind in considering New Zealander's reception of All Quiet on the Western Front. The manner in which the episode brought several major interpretations into relief offers a peek at the state of memory. Thus some emphasised pride in their or a loved one's wartime service, others cited post-war hardships and the threat of new conflicts as invalidating wartime sacrifices, some revalidated the war dead as a lesson that war was unjustifiable, while still others maintained that the war had been a necessary or righteous fight.

The debates over these interpretations also offer a snapshot of public mythologizing of the war. In retrospect, we can glimpse, within the commentary's fault lines, elements that memory would later converge upon. One letter writer's mocking of presentations, which he felt showed that "the Great War was nothing but a great big manly game of football, played strenuously, of course," sound remarkably familiar to the later twentieth-century notions of the war as a tragic and bloody farce. ${ }^{93}$ Indeed, whilst remembrance ceremony would continue to 
encode the war with solemn sentiments, novels, films and plays, inspired by Remarque's work and/or seeking to capitalise on his success, it increasingly developed the sense that the war was fundamentally defined by its inexcusable pointlessness and futile suffering. Over time this would become an assumed point within the popular imagination. ${ }^{94}$

However, with this interpretation being a contested part of a broader sweep of ideas in 1929, we can also examine the relationship between conception and commentators. This examination must cast doubt on theories that men with military service possessed and cherished some manner of unique shared memory of the war. Echoing Paul Fussell, Jock Phillips has argued that frontline experience saw soldiers' cultivate a shared cynical outlook on the war which was hostile to the conventionally patriotic sentiments of the home front. ${ }^{95}$ This "soldiers' view" is argued to have been subsequently suppressed by the "high diction" of post-war remembrance ritual; "By the end of the 1920s, the public memory of the war obscured rather than reflected the view from the front." 96

Many New Zealanders, circa 1929, would disagree with this assessment, and debates over representations of the war are far more jagged than binary notions of disillusioned veterans against a conventionally romantic public allow. ${ }^{97}$ The premise that veterans' valued their experiences in some definitive fashion needs to be considered very carefully in light of how varied outlooks were; many critiqued or rejected cynical representations of the war and/or argued that conventional values and sentiments were fitting and proper. A binary schema is further complicated by how many without frontline experience showed themselves capable of questioning or rejecting idealistic sentiments around war and endorsing representations like Remarque's.

Lastly, this episode reflects the continuing emotional involvement of contemporaries in the memory of the war. Those who voiced their thoughts demonstrated some level of commitment, and often considerable passion, in how the war was represented and how this complemented or clashed with their own memories and outlook. A decade after the war's conclusion, memory of 1914-1918 was not so quiet on the New Zealand front. 
${ }^{1}$ The Month, 2 August 1930, 23.

${ }^{2}$ Cyril Falls, War Books: A Critical Guide (London: Peter Davies Limited, 1930), x.

${ }^{3}$ As one study of memory notes, "Central to every life narrative is the expression of values and beliefs. When these come into conflict with experiences ... individuals struggle to compose a narrative that reconciles past and present, or presents a coherent sense of self." See Anna Green, Cultural History (Basingstoke: Palgrave Macmillan, 2008), 97-98. See also Alistair Thomson, Anzac Memories: Living with the Legend (Melbourne: Oxford University Press, 1994).

${ }^{4}$ Jay Winter, Remembering War: The Great War Between Memory and History in the Twentieth Century (New Haven: Yale University Press, 2006), 238.

${ }^{5}$ Ian McGibbon, "Casualties." in The Oxford Companion To New Zealand Military History, ed. Ian McGibbon (Auckland; Melbourne; Oxford: Oxford University Press, 2000), 80.

${ }^{6}$ Stephen Clarke, "Return, Repatriation, Remembrance and the Returned Soldiers' Association 1916-22." in New Zealand's Great War: New Zealand, The Allies and The First World War, eds John Crawford and Ian McGibbon (Auckland: Exisle Publishing, 2007), 157-180.

${ }^{7}$ One expression of this is evident in the aspirations advanced by the RSA. See Ibid.

${ }^{8}$ Alexander Watson, Enduring the Great War: Combat, Morale and Collapse in the German and British Armies, 1914-1918 (Cambridge: Cambridge University Press, 2008), 7.

${ }^{9}$ Steven Loveridge, Calls to Arms: New Zealand Society and Commitment to the Great War (Wellington: Victoria University Press, 2014), 205-221.

${ }^{10}$ Winter, Remembering War, 238.

${ }^{11} 1020$ men, for example, are noted as having lost limbs. Nicholas Boyack and Jane Tolerton, In the Shadow of War: New Zealand Soldiers Talk About Their Lives (Auckland: Penguin Books, 1990), 248.

${ }^{12}$ For an analysis of ongoing health concerns of New Zealand veterans see Elizabeth Anne Walker, "'The Living Death' The Repatriation Experience of New Zealand's Disabled Great War Servicemen" (master's thesis, Victoria University of Wellington, 2013). For the prominence of 'going home' in the soldiers' mind see David H. Marlowe, Psychological and Psychosocial Consequences of Combat and Deployment with Special Emphasis on the Gulf War (Santa Monica: RAND, 2000), 124. For a New Zealand study which touches on the issue see Coralie Clarkson, "The Reality of Return: Exploring the Experiences of World War One Soldiers after their Return to New Zealand" (master's thesis, Victoria University of Wellington, 2011), 24-54.

${ }^{13}$ Rosa Maria Bracco, Merchants of Hope: British Middlebrow Writers and the First World War, 19191939 (Providence: Berg, 1993), 71.

${ }^{14}$ Gilbert Frankau, Peter Jackson, Cigar Merchant: A Romance of Married Life (London: Hutchinson, 1920), 173.

${ }^{15}$ Paul Fussell, The Great War and Modern Memory (New York: Oxford University Press, 1975). For an account of the continuation of conventional sentiments in wartime remembrance see Jay Winter, Sites of Memory, Sites of Mourning: The Great War in European Cultural History (Cambridge; New York: Cambridge University Press, 1995). Winter responds to the ideas raised in Fussell's work throughout but 
see 2-5 for a particular example. For an assessment of methodological flaws in Fussell's account see Dan Todman, The Great War: Myths and Memory (London: Hambledon Continuum, 2005), 159. For a critique of Fussell's understanding of the military history of the war see R. Prior and T. Wilson, "Paul Fussell at War," War in History 1, 1 (1994): 63-80.

${ }^{16}$ Todman, The Great War, 19.

${ }^{17}$ For further analysis of this work see Scott Worthy, "Light and Shade': The New Zealand Written Remembrance of the Great War, 1915-1939," War \& Society 22, 1 (2004): 19-40.

${ }^{18}$ Hugh Cecil, The Flower of Battle: How Britain Wrote the Great War (London: Secker \& Warburg, 1995), 3. The effect is perhaps comparable to some contemporary representations of the Second World War Saving Private Ryan or Band of Brothers for instance. While these productions feature graphic portrayal of combat and its physical and psychological consequences, they are not typically taken as moral condemnations of the war they graphically depict or as possessing an anti-war message.

${ }^{19}$ See for example Auckland Star, 18 November 1929, 7, Evening Post, 22 November 1929, 10.

${ }^{20}$ Todman, The Great War, 21; Brian Bond, The Unquiet Western Front: Britain's Role in Literature and History (Cambridge: Cambridge University Press, 2002), 33.

${ }^{21}$ Erich Maria Remarque, All Quiet on the Western Front, trans. A.W. Wheen (Heinemann New Windmills, 1990), 176-7.

${ }^{22}$ On imagery see Im Westen Nichts Neues, ed. Brian Murdoch (London: Methuen Educational, 1984), 26. Remarque, All Quiet, 231.

${ }^{23}$ Remarque, All Quiet, 146.

${ }^{24}$ Ibid., preface.

${ }^{25}$ Ibid., 248.

${ }^{26}$ Archives New Zealand-R12681223-ADQZ-18908-WAII11-5, "Papers on economic stabilisation.” Key examples of New Zealand texts which might be considered within this trend include John A. Lee D.C.M., Civilian into Soldier (London: May Fair Books, 1963 - originally published 1937), Robin Hyde, Passport to Hell: The Story of James Douglas Stark, Bomber, Fifth Regiment, New Zealand Expeditionary Forces (London: Hurst \& Blackett, 1937) and Archibald Baxter, We Will Not Cease (Auckland Cape Catley 2003 - originally published 1939).

${ }^{27}$ Murdoch, Im Westen Nichts Neues, 2.

${ }^{28}$ Auckland Star, 2 August 1929, 8; Evening Post, 22 June 1929, 11; Hutt News, 4 July 1929, 7; Otago Daily Times, 1 July 1929, 6.

${ }^{29}$ Ellesmere Guardian, 16 July 1929, 4; Ellesmere Guardian, 9 July 1929, 4; New Zealand Herald, 29 June 1929, 7; New Zealand Herald, 22 June 1929, 15.

${ }^{30}$ Auckland Star, 29 June 1929, 12.

${ }^{31}$ Auckland Star, 2 July 1929, 10; New Zealand Herald, 15 August 1929, 6; Auckland Star, 6 September 1929, 9.

${ }^{32}$ Auckland Star, 11 July 1929, 6.

Journal of New Zealand Studies NS18 (2014), 23-40 
${ }^{33}$ Ibid., 28 October 1929, 6.

${ }^{34}$ This article's title makes one example.

${ }^{35}$ Auckland Star, 17 May 1930, 2.

${ }^{36}$ Censorship regulations note the following edits. The removal of "objectionable" language in the form of two mentions of the word "guts" in dialogue, and the lines "when we come back I'll get you all some nice clean underwear" and "get drunk - and look for women". Cuts to sequences were made to "tone down the sequence of Paul Baumer [sic] in the shell hole with the dying Frenchman," to "eliminate objectionable shots of men bathing in river" and the sequence of "three men visiting girls and spending the night with them." See Archives New Zealand-R22244003-ACGO-8405-IA83-16, "All Quiet on the Western Front."

${ }^{37}$ Auckland Star, 6 July 1929, 1.

${ }^{38}$ Evening Post, 30 July 1929, 8.

${ }^{39}$ Archives New Zealand-R22244003-ACGO-8405-IA83-16, “All Quiet on the Western Front.”

${ }^{40}$ Evening Post, 27 April 1929, 9.

${ }^{41}$ Auckland Star, 1 July 1929, 3.

${ }^{42}$ Ibid., 27 June 1929, 6.

${ }^{43}$ Ibid., 25 June 1929, 6.

${ }^{44}$ Evening Post, 30 July 1929, 8.

${ }^{45}$ Otago Daily Times, 11 May 1929, 4.

${ }^{46}$ New Zealand Herald, 24 June 1929, 14.

${ }^{47}$ Auckland Star, 1 July 1929, 3.

${ }^{48}$ Evening Post, 24 July 1929, 8.

${ }^{49}$ New Zealand Herald, 3 July 1929, 14.

${ }^{50}$ Evening Post, 25 November 1929, 8.

${ }^{51}$ Ibid., 20 July 1929, 8.

${ }^{52}$ Ibid., 9 December 1929, 10.

${ }^{53}$ Ibid., 27 November 1929, 7.

${ }^{54}$ Ibid., 20 November 1929, 13, Evening Post, 25 November 1929, 8.

${ }^{55}$ Ibid., 21November 1929, 8.

${ }^{56}$ Ibid., 22 November 1929, 10.

Journal of New Zealand Studies NS18 (2014), 23-40 
${ }^{57}$ New Zealand Herald, 15 December 1909, 6. For more analysis of this see Steven Loveridge, "'Soldiers and Shirkers': Modernity and New Zealand Masculinity during the Great War," New Zealand Journal of History 47, 1 (April 2013): 59-79.

${ }^{58}$ Loveridge, Calls to Arms, 101-135.

${ }^{59}$ The New Zealand Division's VD rate, noted as the highest within the Empire's troops, is examined in Bronwyn Dalley, "'Come Back with Honour': Prostitution and the New Zealand Soldier, at Home and Abroad." in New Zealand's Great War: New Zealand, The Allies and The First World War, eds John Crawford and Ian McGibbon (Auckland: Exisle Publishing, 2007), 364-377. For some details on the use of alcohol see Nicolas Boyack, Behind the Lines: The Lives of New Zealand Soldiers in the First World War (Wellington: Allen \& Unwin, 1989), 106, 139. The Wazzar riots, the Surafend Massacre and the Sling mutiny - key episodes of disorder - are detailed in Christopher Pugsley, On the Fringe of Hell: New Zealanders and Military Discipline in the First World War (Auckland: Hodder \& Stoughton, 1991), 3132, 286-288, 292.

${ }^{60}$ Loveridge, Calls to Arms, 128-129.

${ }^{61}$ Bracco, Merchants of Hope; Loveridge, "Seeing Trauma as Sacrifice: The Link Between 'Sentimental Equipment' and Endurance in New Zealand's War Effort." in Endurance and the First World War: Experience and Legacies in New Zealand and Australia, eds David Monger, Sarah Murray and Katie Pickles (Newcastle: Cambridge Scholars Publishing, 2014), 49-63.

${ }^{62}$ Auckland Star, April 29 1930, 6.

${ }^{63}$ Lee, Civilian into Soldier, 50.

${ }^{64}$ Evening Post, 31 July 1929, 14.

${ }^{65}$ Auckland Star, 6 July 1929, 1.

${ }^{66}$ Evening Post, 22 November 1929, 10.

${ }^{67}$ The Month, 2 August 1930, 23.

${ }^{68}$ Auckland Star, 25 July 1929, 6.

${ }^{69}$ Evening Post, 26 July 1929, 8.

${ }^{70}$ Ibid., 22 November 1929, 10.

${ }^{71}$ Auckland Star, 25 June 1929, 6.

${ }^{72}$ New Zealand Herald, 23 April 1930, 14.

${ }^{73}$ Ibid., 26 April 1930, 16.

${ }^{74}$ Auckland Star, 29 April 1930, 6.

${ }^{75}$ Evening Post, 20 November 1929, 13.

${ }^{76}$ Cecil Malthus, ANZAC: A Retrospect (Auckland: Reed Publishing, 2002, originally published 1965), 13,18 . 
${ }^{77}$ For a New Zealand context see Elsie Locke, Peace People: A History of Peace Activities in New Zealand (Christchurch: Hazard Press, 1992), 68-78, Archives New Zealand-R12681223-ADQZ-18908-WAII115, "Papers on economic stabilisation."

${ }^{78}$ New Zealand Parliamentary Debates, 225, 15 August 1930, 303.

${ }^{79}$ Auckland Star, 8 July 1929, 6.

${ }^{80}$ Evening Post, 22 November 1929, 10.

${ }^{81}$ Ellesmere Guardian, 16 July 1929, 5.

${ }^{82}$ Otago Daily Times, 12 July 1929, 12.

${ }^{83}$ Evening Post, 23 November 1929, 8.

${ }^{84}$ Ibid., 27 November 1929, 7.

${ }^{85}$ Ibid., 27 November 1929, 7.

${ }^{86}$ Ibid., 25 November 1929, 8.

${ }^{87}$ Ibid., 12 December 1929, 8.

${ }^{88}$ Ibid., 25 November 1929, 8.

${ }^{89}$ The answer provided notes "Are we going to get people to read these books and then refuse to fight? No, there is another way. Get rid of the spirit of hatred and spread the spirit of friendship." Ibid., 9 December 1929, 10.

${ }^{90}$ Green, Cultural History, 97.

${ }^{91}$ Murdoch, Im Westen Nichts Neues, 1; Todman, The Great War, 19.

${ }^{92}$ Thomson, ANZAC Memories, 7-11, 213-215.

${ }^{93}$ Evening Post, 12 December 1929, 8.

${ }^{94}$ Todman.

${ }^{95}$ This has been a recurring point within his work on the subject. See Jock Phillips, "War and National Identity." in Culture and Identity in New Zealand, eds David Novitz and Bill Willmott (Wellington: GP Books, 1989), 91-109; "The Quiet Western Front: The First World War and New Zealand Memory." in Race, Empire and First World War Writing, ed. Santanu Das (New York: Cambridge University Press, 2011), 231-248; "Lest We Forget: Remembering, and Forgetting, New Zealand's First World War." in How We Remember: New Zealander and the First World War, eds Charles Ferrall Harry Ricketts (Wellington: Victoria University Press, 2014).

${ }^{96}$ Phillips, “The Quiet Western Front", 242.

${ }^{97}$ For further analysis see Worthy, "Light and Shade". 